\title{
CSAPATÉPÍTÉS A HR-MENEDZSER ÉS A PSZICHOLÓGUS SZEMSZÖGÉBŐLA
}

\author{
Dr. PhD., PhD. Gulyás László* - Dr. PhD. Turcsányi Enikő ${ }^{* *}$ \\ * docens, Szegedi Tudományegyetem Mérnöki Kar \\ " pszichológus, Csongrád Megyei ÁMK Tanácsadó Központja
}

\section{SUMMARY}

In this paper we study one part of team work's subject, and try to give the main viewspoints of selecting team members. One author of this paper is psychologist, the other one is HR-manager, both of them try to systematize the selections methods of team-members their point of view.

\section{BEVEZETÉS}

2006-ban megjelent tanulmányunkban(1) arra a kérdésre kerestük a választ, hogy a munkavégzés szempontjából mi a hatékonyabb: a csapatmunka vagy az egyéni munkavégzés. Jelen tanulmányban a csapatmunka kérdéskörének egy kisebb szeletét vizsgáljuk meg, megpróbáljuk felvázolni a csapattagok kiválasztásának föbb szempontjait. Véleményünk szerint jelen tanulmányunk érdekességét és újdonságát az adja, hogy az egyik szerzője pszichológus, míg másik szerzője HR-menedzser és mindketten a saját szakmájuk szakirodalmából és gyakorlatából kiindulva próbálják meg rendszerezni a csapattagok kiválasztásának szempontrendszerét.

\section{CSAPATÉPÍTÉS A HR-MENEDZSER SZEMPONTJÁBÓL}

A magyar nyelvü HR-szakirodalmat áttanulmányozva(2) azt a kijelentést kell tennünk, hogy ha a HR-menedzserek csapatépítési feladatot kapnak, alapvetően az alábbi három kérdés mentén kezdenek el gondolkodni:

1. A csoport nagysága.

2. A csoport jellege.

3. A csoporttagok szakmai felkészültségének kívánatos szintje.

A kővetkező alfejezetekben áttekintjük a fenti három terület jellemzöit. Itt jelezzük, hogy tanulmányunkban a csoport szót a csapat szinonímájaként használjuk.

\subsection{A csoport nagysága}

Az ideális csoportnagyság jelentős mértékben függ a csoport által elvégzendő feladat jellegétől, ezen belül pedig a munkavégzés technológiájától. Általános tapasztalatként rögzíthetjük, hogy minél komplexebb feladatot kell megoldania egy csoportnak, annál nagyobb csoportra van szükség, azért, hogy a feladat minden egyes részfeladatát megfelelő szakemberre lehessen bízni. Ezzel ellentétes vezetői tapasztalat, hogy a kisebb létszámú csoportok könnyebben vezethetők.

Ezzel szemben a szociálpszichológusok arra a véleményre helyezkednek, hogy a csoportlétszám és a teljesítmény között kifejezetten negatív kapcsolat van(3). A HR- 
szakemberek - és föleg az ö főnökeik - a fentebb felsorolt tapasztalatok közül inkább az első tapasztalatot tartják fontosnak. Többnyire csupán az lebeg a szemük elött, hogy két 15 föből álló csoportnak két vezetöre lenne szüksége, míg egy 30 emberből álló csoportnak csupán egyre. Ezért 30 fös csoportot hoznak létre. Söt ha némely magyar város - például Hódmezővásárhely - általános iskolákat érintő összevonási gyakorlatát vizsgáljuk, akkor azt látjuk, hogy 10-12 iskola élére neveznek ki egy igazgatót, ami gyakorlatilag százas nagyságrendủ beosztott tanári csapatot jelent.

A HR-szakember igazi feladata, hogy megtalálja az elvégzendő munka jellegének és a megoldandó feladatnak leginkább megfelelö csoportnagyságot, miközben nemcsak a müszaki, technikai és pénzügyi vonatkozásokat veszi figyelembe, hanem a csoportok müködését meghatározó emberi törvényszerüségeket is.

\subsection{A csoport jellege}

A HR-szakirodalom(4) a munkacsoportokat általában formális és informális csoportokra szokta bontani. Tanulmányunk témája szempontjából azonban sokkal fontosabbnak tartjuk Klein Sándor csoportositását(5), mely szerint léteznek heterogén illetve homogén csoportok.

Ha a csoportot egymáshoz - érdeklödés, személyiség, képesség, etc. tekintetében hasonló dolgozókból állítjuk össze, akkor homogén csoportról beszélünk. Ha a csoporttagok a fentebb említett dimenziók mentén eltérnek egymástól, heterogén csoportról beszélünk.

A homogén és heterogén csoportok müködését és teljesítményét összehasonlítva az alábbi megállapításokat tehetjük(6): A homogén csoport teljesítménye nagyobb a heterogén csoporténál, abban az esetben ha a feladat viszonylag egyszerü és a csoport teljesítménye a dolgozók konfliktusmentes koordinált együttmüködésétől függ. Ezzel szemben a heterogén csoportok az alábbi esetekben tudnak jobb teljesítményt nyújtani:

1. Komplex feladatoknál, ahol kifejezetten szükség van a tagok egymástól eltéró tulajdonságaira. Belbin szerint ezek az eltérő tulajdonságok teszik lehetővé, hogy a csapaton belül az egyes csapattagok különféle szerepeket - Vállalatépítő, Elnök, Ötletgyáros, Forrásfeltáró, Helyzetértékelő, Csapatjátékos, Megvalósító - tudnak betölteni(7).

2. Olyan esetekben, ahol a feladat gyors megoldása kifejezetten hátrányos (lásd például az esküdtszékek müködését).

3. Kreativitást igénylő feladatoknál.

A heterogén csapat kialakításánál igazi kihívás abban fogható meg, hogy hogyan lehet különböző hátterü, eltérő tapasztalatokkal rendelkező és különféle személyiségü emberekből hatékony - vagy másképpen fogalmazva termelékeny - csapatot kialakítani(8). William Hitt pontosan ezért helyezkedett arra az álláspontra, hogy a kiváló vezető - az ő szóhasználata szerint a mestervezető - egyik legfontosabb kompetenciája a csapatépítés képessége(9).

\subsection{A csoporttagok szakmai felkészültségének kívánatos szintje}

A csapatépitő HR-szakembernek tisztában kell lennie azzal, hogy egy-egy csapattagnak milyen tulajdonságokkal kell rendelkeznie, annak érdekében, hogy a csapaton belül ráosztott feladatot a lehető legjobban el tudja látni. Az 1. ábrán - pontosabban annak középsö részén - láthatjuk ezt a követelményt egy szélesebb keretbe, magába a humán erőforrás menedzsment folyamatába ágyazva. 


\section{1. ábra: A humán erõforrás menedzsment folyamata}

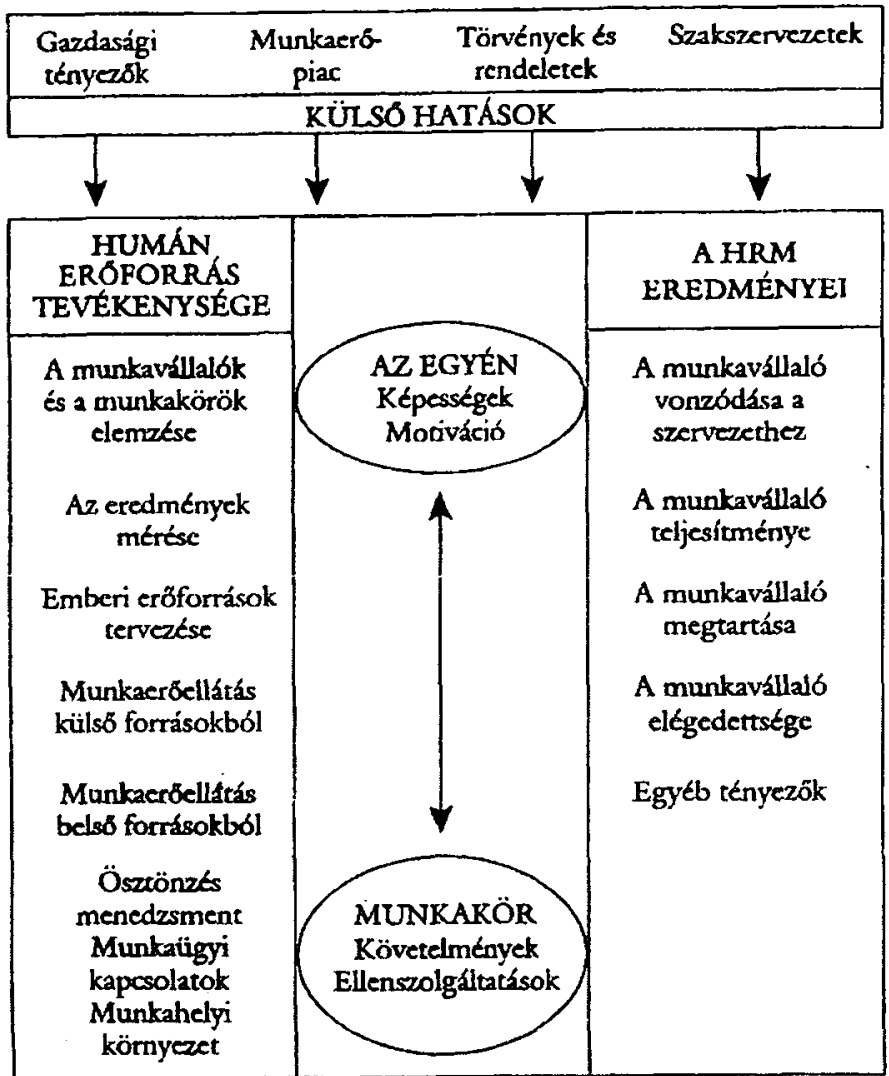

Forrás: Henamann et al. (1986): Human resource management Irwin Inc. Illinois 8. old.

Az ábra középső oszlopa a HR-tevékenység egyik kulcsfeladatát mutatja be, ez pedig az egyén illesztése a munkakörhöz, ill. a munkakör illesztése a egyénhez. Az egyének (a munkavállalók) eltérỏ képességekkel és eltérỏ motivációkkal rendelkeznek. Gyakorlatilag az egyéni képességek és az egyéni motivációk kombinációja határozza meg az egyén munkateljesitményét.

A. képességek és a motivációk azonban nem egy vákuumban fejtik ki hatásukat, hanem az elvégzendö munka (a munkakör) is meghatározza kombinációjukat. Ugyanis minden munkának megvan a saját követelményrendszere. Legnyilvánvalóbb a képességek követelményrendszere, pl. hogy a munkavállalónak legyen diplomája, vagy legyen valamilyen speciális képessége. A munkavállalóval szemben támasztott követelmények együtt jámak bizonyos ellentételezésekkel. Ilyenek a fizetés, juttatások, továbbá lehetőség a fejlődésre, karrier, kihívás, felelősség etc. Mindegyik ellentételezésnek hatása van a munkavállaló motivációjára és igényeinek kielégítésére.

A modell középső része azt kívánja szemléltetni, hogy a munkavállaló képességeinek ẻs motivációjának illeszkednie kell az állás követelményeihez és az ellentételezésekhez(10). Még tovább bonyolitja a kérdéskört az a helyzet ha az egyénnek nem csupán egyénként kell illeszkednie a munkakörhöz, hanem csapattagként a csapathoz is illeszkednie kell. 
A HR-szakemberek az utóbbi években az illeszkedés vizsgálatához a kompetencia fogalmát kezdték el használni. Kompetencia alatt a HRM-ben az alábbiakat értve: Azokat az alapvető tulajdonságokat nevezzük kompetenciának, amelyek eredményeként az adott munkakörben egy munkatárs magatartás alapján értékelhetö, elöre meghatározott kritériumok szerint jó/kiváló teljesitményt nyújt(11).

A kompetenciák beemelése a HR-folyamatokba a HR-szakember számára az alábbi négy feladatot jelenti:

1. A kompetenciák segítségével leírja az adott munkafeladat ellátásához szükséges magatartást.

2. A kiválasztás folyamata során vizsgálja, hogy a jelöltek közül kik rendelkeznek a betöltendỏ álláshoz szükséges kompetenciákkal.

3. A kompetenciák segítségével mủködteti a teljesítményértékelő rendszert.

4. A képzési/fejlesztési rendszert oly módon kialakítani, hogy annak célja a vállalati siker szempontjából kulcsfontosságú kompetenciák fejlesztése legyen.

A kompetenciák felhasználásával müködtetett HRM-rendszerekben a csapatépítés folyamata is a kompetenciák mentén történik. Például egy-egy potenciális csapattagjelöltnél azt vizsgálják, hogy rendelkezik-e azon kompetenciákkal, amelyek lehetővé teszik a csapatba történő beillesztését és az ottani eredményes munkavégzését.

\section{CSAPATÉPÍTÉS A PSZICHOLÓGUS SZEMPONTJÁBÓL}

Tanulmányunk 2. fejezetében láthattuk, hogy milyen szakmai kritériumok mentén gondolkodnak a HR-szakemberek csapatépítési munkájuk során. Jelen alfejezetben azt vizsgáljuk meg, hogy a fentiekhez mit tud hozzá tenni a pszichológia, pontosabban a szociálés munkapszichológia.

A szakirodalom áttekintése után(12) az a véleményünk alakult ki, hogy ha a pszichológusok csapatépítésröl beszélnek, akkor elsösorban a potenciális csapattagok interperszonális készségeinek szintjéböl indulnak ki. Véleményünk szerint az interperszonális képességek alábbi három csoportját érdemes megvizsgálni(13):

1. Személyiségjegyek

2. Másokkal szembeni viselkedés

3. Kommunikációs készség

A következő alfejezetekben áttekintjük ezeket a csoportokat és bemutatjuk jellemzőiket.

\subsection{A személyiségjegyek}

A személyiségpszichológia szerint az emberek olyan állandó jellemzőkkel - vonások rendelkeznek, amelyek különböző időben és különböző körülmények között nyilvánulnak meg(14). A vonáselméleti pszichológiai iskolához tartozó pszichológusok - Cattel, Eysenck számos személyiségvonást különböztetnek meg, véleményünk szerint ezen személyiségvonások közül a csapatépítés szempontjából három fontos vonást kell megvizsgálni(15).

Elöször is fel kell tárni, hogy az adott egyén milyen értékeket vall az a másokkal való együtt-dolgozás tekintetében: Elképzelhető olyan szituáció, hogy a potenciális csapattag HRszempontból - azaz szakmai szempontból - tökéletesen megfelelne, de nem tud vagy nem akar csapatban dolgozni, mivel a W. D. Hitt-féle „magányos hős” kategóriába tartozik(16). 
Másodszor meg kell vizsgálni, hogy az adott egyén a kezdeményezőkészség terén hol helyezkedik el. Az egyén kezdeményezõen lép fel vagy csak az eseményeket követi a problémamegoldás során. A problémamegoldás tekintetében egyénenként változik az ún. problémaérzékenység. Az egyik csapattag rendelkezhet olyan képességgel, amely segítségével képes az egész rendszert átlátni, pontosan érti, hogy a rendszer nagyobb összetevői mily módon illeszkednek egymáshoz, de közben nem tud figyelni a részletekre. Míg egy másik csapattag a részletekre való odafigyelésben van otthon, de nem érti a nagyobb összefüggéseket. Elméletileg a csoportot azért hozzuk létre, hogy a fenti két ember kủlönbözőségéböl szinergiát teremtsünk. Természetesen ezen kérdés vizsgálatánál fontos annak elözetes meghatározása, hogy pontosan milyen szerepre is keresünk csapattagot. Ha például a Belbin-féle szerepekből(17) - Vállalatépítő, Elnök, Ötletgyáros, Forrásfeltáró, Helyzetértékelő, Csapatjátékos, Megvalósító - indulunk ki, korántsem mindegy, hogy „Ötletgyárost” vagy „Megvalósítót” keresünk.

Harmadjára a feszültségtürést kell szemügyre venni. Vizsgálandó kérdés: Rendelkezik-e az egyén olyan készségekkel, melyek segítségével kezelni tudja azokat a feszültségeket, amelyek a csapatmunka során keletkeznek? A csapatmunka számos stresszforrást - szorító határidők, panaszkodó vagy éppen ellenségeskedő kollégák, szerepkonfliktusok, túlterheltség, etc. - rejt magában, ezért nagyon fontos, hogy a fellépö stresszre az adott dolgozó megfelelő megküzdési stratégiákkal tudjon válaszolni(18). Nincs egyetlen tökéletes megküzdési stratégia, ehelyett számos különféle stressz-oldó technika létezik, de ezek közös tulajdonsága, hogy segitenek a stressz legyőzésében, a pszichés jólét megörzésében és a fizikai egészség megóvásában(19).

\subsection{Másokkal szembeni viselkedés}

Ebben a mezőben a csapatépités szempontjából négy fontos területet kell vizsgálnunk. Egyrészt vizsgálnunk kell a potenciális csapattag befolyásolással kapcsolatos viselkedését. Pontosabban azt kell feltárnunk, hogy: Milyen módszereket használ az adott egyén a többiek befolyásolására? Másképpen fogalmazva milyen technikákat használ a többiek meggyőzésére?(20) William Hitt hívja fel arra a figyelmet, hogy a manipuláció milyen káros a csoportkohézió szempontjából(21).

Másodjára fel kell tárni a potenciális csapattag érzékenységének fokát. A vizsgálandó kérdés az, hogy: Mutat-e az adott egyén érzékenységet mások érzései és gondolatai iránt? Úgy véljük, hogy az empátia, azaz a mások helyzetébe való őszinte belehelyezkedés képessége nélkül senki sem válhat csapattaggá(22). Goleman szerint azok, akik rendelkeznek empátiával az alábbi három mezöben nyưjtanak jó teljesítményt(23):

1. Figyelnek az érzelmi jelzésekre, és meg tudnak hallgatni másokat.

2. Mások látásmódja iránt érzékenységet mutatnak, megértik perspektíváikat.

3. Mások szükségleteinek és érzéseinek megértése alapján nyújtanak segitséget.

A jó csapat egyik legfontosabb tulajdonsága, hogy tagjait nem hagyja közömbösen az, ami a többiekkel történik.

Harmadjára meg kell ismernünk az adott egyénnek a csapatmunka során szerzett tapasztalatait. A legfontosabb megválaszolandỏ kẻrdés: Volt-e mảr az adott egyén korábban beosztottainak vagy társainak tanácsadója vagy instruktora? Ha a csapatagot külsỏ toborzási forrásból biztosítjuk, akkor ennek a kérdésnek az interjú során kell elökerülnie. Ha viszont a csapattagot belsỏ toborzási forrásból biztosítjuk, akkor az ún. menedzserleltárból is választ kaphatunk erre a kérdésre. 
A negyedik vizsgálati szempont a megbízhatóság. Azaz teljesíti-e az adott egyén a rábízott feladatot. Erre a kérdésre kétfajta forrásból kaphatunk választ. Egyrészt szóba jöhet a korábbi munkahelyekről bekért referencia. Másrészt olyan személyiségteszt kitöltetése, amely válaszolni tud erre a kérdésre.

\subsection{Kommunikációs készségek}

Ebben a mezöben a csapatépítés szempontjából egy fontos kérdést kell megvizsgálnunk, az adott egyén párbeszédkészséget(24). A párbeszéd fogalmának definiálásához Martin Bubber megfogalmazását használjuk, mely szerint három fajta kommunikáció létezik: ${ }^{25}$

1. Monológ: egyirányú kommunikáció, amelyben van adó, de nincs vevő. Nincs igazi párbeszéd.

2. Technikai kommunikáció: Két irányú kommunikáció, van adó és van vevő és közöttük információcsere történik, de ez még nem igazi párbeszéd.

3. Párbeszéd: Annyival több mint a technikai kommunikáció, hogy nem csupán információcsere történik, hanem a kölcsönös bizalom mentén igazi becsületes kommunikáció zajlik le az adó és a vevö között.

\section{2. ábra: A munkahelyi kommunikáció formái}

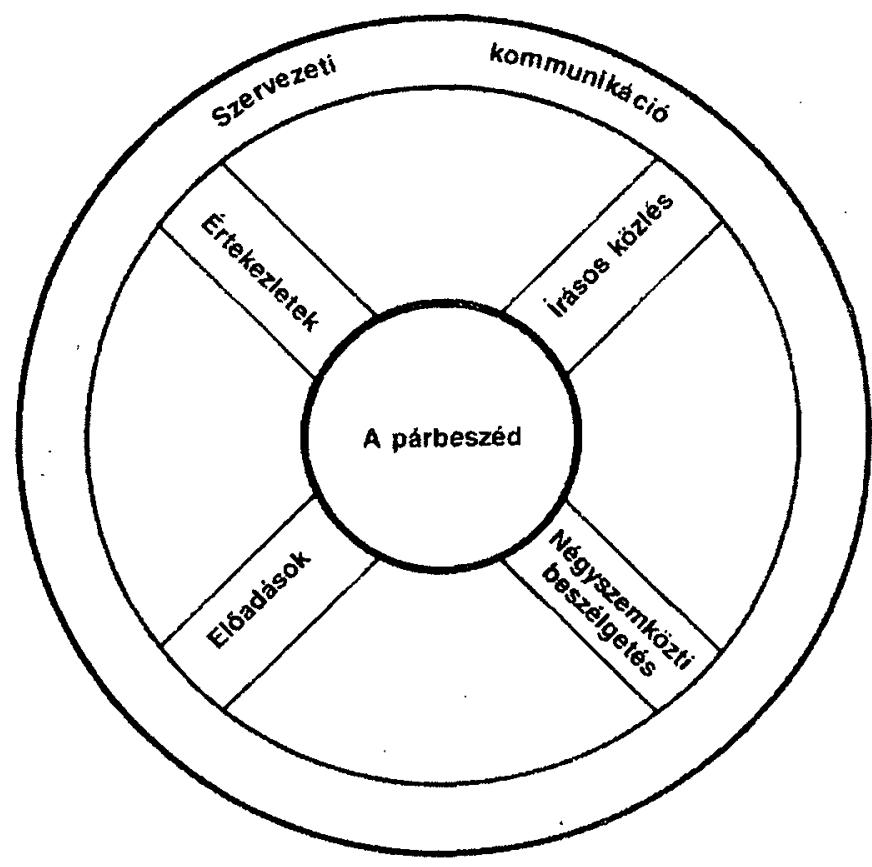

Forrás: W. D. Hitt (1990): A mestervezetó. OMIK. Budapest. 134. old.

William Hitt könyvében arra az álláspontra helyezkedik, hogy jó csapatot csak akkor lehet kialakítani, ha a csapat kommunikációját a párbeszéd uralja. Mint a 2. ábráról látható, 
William Hitt szerint a munkahelyen a párbeszéd négyféle formában történik. 1. értekezlet 2 . előadások 3. négyszemközti beszélgetések 4. írásos közlések.

Ezen Hitt-féle gondolatmenetbỏl logikusan adódik, hogy annak a kérdésnek az eldöntéséhez, mely szerint rendelkezik-e a potenciális csapattag a munkavégzéshez szükséges hatékony kommunikáció képességével, az alábbi kettö kérdést kell fel tennünk:

1. Képes-e a potenciális csapattag mások számára érthetõen és a lényegre összpontosítva előadni gondolatait? Ezzel a kérdéssel lefedjük az 1-3 párbeszédformákat.

2. Mennyire hatékonyan tudja a potenciális csapattag gondolatait írott formába önteni.

Véleményünk szerint a 2 . ábrából adódó fenti két kérdést még további két kérdéssel kell kiegészitenünk:

1. Milyen megértési készségekkel rendelkezik az adott egyén. Azaz: Mennyire tudja a potenciális csapattag hatékonyan befogadni, megérteni az élőszóban (előadás, értekezlet, négyszemközti beszélgetés) elhangzott új információkat?

2. Milyen olvasási készségekkel rendelkezik az adott egyén. Azaz: Mennyire tudja a potenciális csapattag hatékonyan befogadni az úi információkat olvasás útján?

Összefoglalva az ezen alfejezetben elmondottakat, sikeres csapattag csak az lehet, aki a fentebb tárgyalt kommunikációs formákat sikeresen tudja alkalmazni.

\section{KONKLÚZIóK}

Véleményünk szerint a csapatépités egy rendkivül összetett folyamat, melynek sikeréhez nem elegendő a szük HR-szempontok - amelyek elsösorban a technológiáról, a pénzügyi korlátokról, továbbá a vállalati stratégiáról és azzal szoros kapcsolatban lévő HRstratégiáról szólnak - figyelembevétele. A csapatépítés területén a szociálpszichológiának és a munkapszichológiának is van mondanivalója a HRM szakma számára. Az eredményes munkára törekvő HR-szakember odafigyel a szociálpszichológia kutatási eredményeire és felhasználja azt mindennapi munkája során. Az emberi viselkedés törvényszerüségeinek ismerete, a csoportfolyamatok és a csoportdinamika ismerete elengedhetetlen követelmény azon HR-szakemberek számára, akik jó csapatépítővé kívánnak válni. Kijelenthetjük, hogy a kiváló csapatépitő nem csupán kiváló HR-szakember, hanem kiváló alkalmazott pszichológus is.

Viszonylag új kutatási terület a csapatépités az agrárgazdaságban müködő kisebb és nagyobb cégei esetében (25). Tervezzük, hogy együttmüködve a Debreceni Egyetem ilyen irányba kutató $\mathrm{PhD}$-iskolájával $(26,27)$. vizsgálatainkat ezen speciális irányba is kiterjesszük.

\section{JEGYZETEK}

1. Gulyás-Turcsányi 2006: A munkavégzési rendszerek egyik kulcskérdése: csapatmunka vagy egyéni munkavégzés? SZTE-SZÉF Ökonómia és Vidékfejlesztési Intézet 2006. évi Tudományos Évkönyve. 23-31. old

2. Tipikus példa erre Bakacsi et. al. (1999): Stratégia emberi erőforrás menedzsment. KJK. Budapest. 81-100. old.

3. Erre vonatkozóan lásd a „társas lazsálás” és a „potyautas-effektussal” kapcsolatos szociálpszichológiai kutatási eredményeket Hewstone et al. (1995): Szociálpszichológia. Közgazdasági és Jogi Könyvkiadó. Budapest.

4. Lásd például Pálinkás Jenő-Vámosi Zoltán (2002): Emberi erőforrás menedzsment. LSI Oktató Központ. Budapest. 176-178. old.; Gyökér Irén (1999): Humánerőforrás menedzsment. Müszaki Könyvkiadó. Budapest. 81. old. 
5. Klein Sándor (2001): Vezetés- és szervezéspszichológia. SHL-könyvek. Budapest. 267. old.

6. Klein Sándor (2001): Vezetés- és szervezéspszichológia. SHL-könyvek. Budapest. 267-268. old.

7. Meredith Belbin (2000): A team, avagy az együttmüködő csoport. SHL-Könyvek. Budapest.

8. William Dyer (1977): Team building: Issues and alternatives. Addison-Wesley Publishing Company. Reading, Massachusetts.

9. Erről bővebben lásd W. D. Hitt (1990): A mestervezető. OMIK. Budapest. 83-99. old.

10. Gulyás L. (2006): A humán erőforrás menedzsment alapjai. JATEPress-Szegedi Egyetemi Kiadó. Szeged. 42. old.

11. Bakacsi et. al. (1999): Stratégia emberi erőforrás menedzsment. Közgazdasági és Jogi Könyvkiadó. Budapest. 111. old.

12. Kiindulási pontként Klein Sándor 5. és 6. lábjegyzetben említett könyve mellett használtuk másik fontos alapmủvét - lásd Klein Sándor (2001): Vezetés- és szervezéspszichológia. SHL-könyvek. Budapest. - továbbá az alábbi könyveket: Carver-Scheier (1998): Személyiségpszichológia. Osiris Kiadó. Budapest; Forgách (1993): A társas érintkezés pszichológiája. Gondolat Kiadó. Budapest; Hewstone et. al. (1995): Szociálpszichológia. Közgazdasági és Jogi Könyvkiadó. Budapest; Smith-Mackie (2004): Szociálpszichológia. Osiris Kiadó. Közgazdasági és Budapest.

13. Kiindulási pontunk Spigel-Torres 1998: Csapatmunka. Részvétel könyvek. Budapest. 31. oldala volt, de az ottani felsorolást módosítottuk, mivel úgy gondoltuk, hogy a Spiegel-Torrres szerzőpáros által „adminisztrativ készségeknek” nevezett tulajdonságcsoport nem a tartozik az interperszonális készségek körébe.

14. Carver-Scheier 1998: Személyiségpszichológia. Osiris Kiadó. Budapest. 1998. 71. old.

15. Spigel-Torres 1998: Csapatmunka. Részvétel könyvek. Budapest. 31-32. old.

16. A magányos hősről bövebben lásd W. D. Hitt 1990: A mestervezetỏ. 71-73. old.

17. Meredith Belbin (2000): A team, avagy az égyüttmüködő csoport. SHL-Könyvek. Budapest.

18. Az ún. megküzdési stratégiákról lásd Smith-Mackie (2004): Szociálpszichológia... 230-251. old.

19. Selye János (1983): Stressz distressz nélkül. Akadémiai Kiadó. Budapest.

20. A meggyőzés különféle lehetséges útjairól lásd bővebben Pratkanis-Aronson (1992): A rábeszélögép. AB OVO Kiadó. Budapest, továbbá Smith-Mackie 2004: Szociálpszichológia. Osiris Kiadó. Budapest. 387-406. old.

21. W. D. Hitt (1990): A mestervezető. OMIK. Budapest. 77. old.

22. Az empátiáról lásd Buda Béla (2006): Az empátia. A beleélés lélektana. Urbis Könyvkiadó. 5. kiadás. Budapest.

23. Daniel Goleman (2002): Érzelmi intelligencia a munkahelyen. SHL-Könyvek. Budapest.

24. Erröl bővebben lásd W. D. Hitt: A mestervezető címü könyvének a munkahelyi kommunikációról szóló fejezetét, 131-150. old.

25. Martin Bubber (1955): Between man and Man. Beacon Press. Boston

26. Berde Csaba (2003): Menedzsment a mezőgazdaságban. Vezetési módszerek és sajátosságok. Szaktudás Kiadó, Budapest, 2003. 237. old

27. Berde Cs - Piros M (2005): Qualification and Human Reseources Management in Hungarian Agriculture. Studies, No. 103. Budapest, 2005. 129-139. old.

28. Berde Csaba (2006): Researches in Human Reseource Management in the Hungarian Agriculture. Jahrbuch der Österreichischen Gesellschaft für Agrarökonomie. Band 15, Wien, 2006. 156-165. old.

\section{FELHASZNÁLT IRODALOM}

Bakacsi et. al. (1999): Stratégia emberi erőforrás menedzsment. Közgazdasági és Jogi Könyvkiadó. Budapest.

Berde Csaba (2003): Menedzsment a mezógazdaságban. Vezetési módszerek és sajátosságok. Szaktudás Kiadó, Budapest, 2003. 237. old.

Berde Cs - Piros M (2005): Qualification and Human Reseources Management in Hungarian Agriculture. Studies, No. 103. Budapest, 2005. 129-139. old. 
Berde Csaba (2006): Researches in Human Reseource Management in the Hungarian Agriculture. Jahrbuch der Österreichischen Gesellschaft für Agrarökonomie. Band 15, Wien, 2006. 156-165. old.

Meredith Belbin (2000): A team, avagy az együttmükbdő csapat. SHL Könyvek. Budapest. Martin Bubber (1955): Between man and Man. Beacon Press. Boston

Buda Béla (2006): Az empátia. A beleélés lélektana. Urbis Könyvkiadó. 5. kiadás. Budapest.

Carver-Scheier (1998): Személyiségpszichológia. Osiris Kiadó. Budapest. 1998.

William Dyer (1977): Team building: Issues and alternatives. Addison-Wesley Publishing Company. Reading, Massachusetts.

Forgách (1993): A társas érintkezés pszichológiaja. Gondolat Kiadó. Budapest.

Daniel Goleman (2002): Érzelmi intelligencia a munkahelyen. SHL-Könyvek. Budapest.

Gulyás László (2006): A humán erōforrás menedzsment alapjai. JATEPress-Szegedi Egyetemi Kiadó. Szeged.

Gulyás L.-Turcsányi E. (2006): A munkavégzési rendszerek egyik kulcskérdése: csapatmunka vagy egyéni munkavégzés? SZTE-SZÉF Ökonómia és Vidékfejlesztési Intézet 2006. évi Tudományos Évkönyve. 23-31. old.

Hewstone et. al. (1995): Szociálpszichológia. Közgazdasági és Jogi Könyvkiadó.. Budapest.

William D. Hiti (1990): A mestervezetō. OMIK. Budapest.

Klein Sándor (1998): Munkapszichológia. SHL-könyvek. Budapest;

Klein Sándor (2001): Vezetés- és szervezetpszichológia. I-II. kötet. SHL Könyvek. Budapest.

Pálinkás J.-Vámosi Z. (2002): Emberi erőforrás menedzsment. LSI Oktató Központ. Budapest.

Pratkanis-Aronson (1992): A rábeszélőgép. AB OVO Kiadó. Budapest,

Selye János (1983): Stressz distressz nélkül. Akadémiai Kiadó. Budapest.

Smith-Mackie (2004): Szociálpszichológia. Osiris Kiadó. Budapest.

Spigel-Torres (1998). Csapatmunka. Részvétel könyvek. Budapest. 